\title{
Impact of Charcoal Production on Physical and Chemical Properties of Soil in the Central Gonja District of the Northern Region, Ghana
}

\author{
S. Wahabu ${ }^{1}$, B. Y. Fosu-Mensah ${ }^{1} \&$ F. K. Nyame ${ }^{2}$ \\ ${ }^{1}$ Institute for Environment and Sanitation Studies (IESS), University of Ghana, P. O. Box 209, Accra, Ghana \\ ${ }^{2}$ Department of Geology and Resource Development, University of Ghana, Legon, Accra, Ghana \\ Correspondence: B. Y. Fosu-Mensah, Institute for Environment and Sanitation Studies (IESS), University of \\ Ghana, Legon, Accra, Ghana. E-mail: yayrafosub@yahoo.com
}

Received: April 7, 2015 Accepted: May 11, 2015 Online Published: June 26, 2015

doi:10.5539/enrr.v5n3p11 URL: http://dx.doi.org/10.5539/enrr.v5n3p11

\begin{abstract}
Charcoal production, is one of the major drivers of land-cover change in Ghana. The trade has in recent time increased in the Central Gonja District of northern Ghana known to be one of the major food baskets of the country. This study assessed the impact of charcoal production on soil properties in the Central Gonja District of Ghana. Composite and core samples (60 samples) from ten (10) randomly selected sites were taken from 0-30 and 30-60 cm depths at the charcoal production site (CPS) and its adjacent field soils, which served as the control (CS). The samples were analyzed for soil texture, exchangeable bases, organic matter, percent carbon, total nitrogen, saturated hydraulic conductivity and electrical conductivity. The results showed that charcoal production site $(\mathrm{CPS})$ had significantly $(\mathrm{p}<0.01)$ higher content of sand, potassium, hydraulic conductivity and electrical conductivity than the control site (CS) within $0-30 \mathrm{~cm}$ depth. Magnesium, calcium, sodium and percent carbon content decreased by 45.7, 2.7, 15.4 and 46.7\% respectively in CPS when compared to CS within the top soil $0-30 \mathrm{~cm}$. Hydraulic conductivity significantly $\left(\mathrm{p}<0.01\right.$ ) increased from $0.5 \pm 0.3$ (CS) to $1.8 \pm 1.0 \mathrm{~h}^{-1}$ (CPS), which is an increase of about $72 \%$ in CPS due to soil heating. Soil organic matter in CPS decreases by $44 \%$ when compared with the CP site. There is a need for further research on the impact of charcoal production on soil nutrient, hydrology and crop production.
\end{abstract}

Keywords: forest, environment, land degradation, soil properties, charcoal, nutrients

\section{Introduction}

The exploitation of resources from the environment through farming, fishing, mining, lumbering, fuel wood and charcoal production among others have socio-economic, environmental and policy implications to countries, especially when they are not well regulated (Nyame \& Danso, 2006). Vegetation and soil degradation have become a major concern to environmental activists in many parts of the world as major parts of the world vegetation has been transformed and soils losing its fertility mostly due to human activities (Bainbridge, 2007). In many instants areas which were ones highly forested have been reduced to dry or desert lands while desert conditions keep on crippling into vegetation zones (Bainbridge, 2007; Arnalds et al., 2001). The production of food and energy has been identified as major cause of environmental degradation across the globe (Eswaran et al., 2001; Bojo, 1996). It is estimated that about $25 \%$ of the world's forest harvested for fuel is converted into charcoal for domestic and industrial purposes (FAO, 1987).

The increase in population in many developing countries has not seen an increase in alternative energy supply over the period, making fuel wood and charcoal use unavoidable (Chidumayo, 2011; Ikurekong et al., 2009; Kammen \& Lew, 2005). As a result, the traditional energy source (fuel wood and charcoal) remains the most used (Malimbwi et al., 2004; World Bank, 1992). FAO (1987) reported that about $54-71 \%$ of households in urban Sub Saharan Africa use charcoal and over 1 million families in Sub Saharan Africa use charcoal as their main source of energy in the urban area.

In addition, FAO (2000) estimate the market value of charcoal in Sub Saharan Africa to be US $\$ 60$ million while the Ghana Energy Commission (2010) reported that over six hundred thousand small to medium scale industries in Ghana are fuelled by charcoal. 
Despite the role charcoal plays as energy and source of income, the production of charcoal has been associated with environmental degradation through the loss in soil organic carbon (C), macro- organisms as well as oxidation of carbon into carbon dioxide (Parker et al., 2010; and Nkongolo et al., 2008). Burning also results in plants stock depression and biodiversity loss (Syaufina and Ainuddin, 2011; Stefan, 2009). In addition, research reports indicate that soil characteristics and mineralogy, especially at the kiln site are significantly affected (Kettering et al., 2000 as cited in Oguntunde et al., 2004), with its consequence on soil fertility and hence food production. Msuya et al. (2011) identified forest depletion and air pollution as some environmental impacts of charcoal production. They estimated the combined effects of charcoal production and use at about 49700000,9 830000,1109000 and 12478000 tons of carbon dioxide, Nitrogen oxide, Sulphur dioxide and Methane respectively in Tanzania. The impact on human health and the environment could be far reaching, including its contribution to the depletion of the ozone layer; which many scientists have attributed to the unpredictable weather patterns and the global increase in diseases.

The impact of charcoal production on soil properties is critical, as soil nutrients such as nitrogen and phosphorous have a profound impact on crop production (Fosu-Mensah, 2012). In Ghana, timber logging, charcoal production and farming contribute to woodland and forest degradation.

The Northern region of Ghana where Central Gonja District is located is known to be one of the major food baskets of the country. However, there is a decreasing trend in the yield of crops over the years due to decline in soil fertility. Farmers are unable to purchase fertilizer to boost crop production due to high cost of fertilizer (Fosu et al., 2004).

In recent years there is an increase in charcoal production in the district using the kiln method. The burning of charcoal has resulted in an indiscriminate felling of tress leaving large stretch of land without tress. This development is having a negative impact on the environment and it's perceive to further depletes the already poor soils in the area. Most of the sites where charcoal production is taking place are agricultural lands where active crop production takes place during the wet season.

There is, however, little information on the impact of charcoal production on soil properties and hence food production in the district. This study assesses the impact of charcoal production on soil properties in the Central Gonja District of Northern Ghana.

\section{Materials and Methods}

\subsection{Study Area}

The Central Gonja District is located at the South Western part of the Northern Region of Ghana. The district lies within longitude $1^{\circ} 5^{\prime}$ and $2^{\circ} 58^{\prime}$ West and latitude $8^{\circ} 32^{\prime}$ and $10^{\circ} 2^{\prime}$ North. The District covers approximately $8,353 \mathrm{~km}^{2}$, which represents $12 \%$ of the total land area of the Northern Region. The topography is generally undulating with an altitude of between 150-200 meters above sea level. The daily temperatures range from $24^{\circ} \mathrm{C}$ to $37^{\circ} \mathrm{C}$. The mean annual rainfall is about $1144 \mathrm{~mm}$. The natural vegetation is characteristics of guinea savannah dominated by Butyrospermum parkii (Shea), Parkia clappertonniana (Dawadawa), Adansonia dititata (Baobab), Acacia sp. (Acacia), Azadirachta indica (Neem) and Khaya senegalensis (Ebony).

\subsection{Soil Sampling}

Ten charcoal production sites were randomly selected, where six soil samples (composite sampling) were taken per site at two depths $(0-30$, and $30-60 \mathrm{~cm})$ using a soil auger from October, 2012 to January, 2013. Site selection was based on evidence of charcoal production within the last six months. Soils from the adjacent fields were taken from a distance of $15 \mathrm{~m}$ away from the edge of the kilns or burnt site (CPS) and used as the control site (CS). The samples were air dried and passed through a $2 \mathrm{~mm}$ sieve and subsample taken to Ecological Laboratory of the University of Ghana for physical and chemical analysis.

\subsection{Soil Analysis}

The soil properties analyzed were soil particle size distribution, $\mathrm{pH}$, carbon, total nitrogen, Organic carbon, exchangeable cations: $\mathrm{K}^{+}, \mathrm{Ca}^{2+}, \mathrm{Na}^{+}, \mathrm{Mg}^{2+}$, electrical conductivity and hydraulic conductivity.

The Hydrometer method was used to determine the physical proportions of the soil using the settling rates. This method is based on the dispersion of soil aggregates using sodium hexametaphosphate solution and subsequent measurement based on changes in suspension density (Dietrich, 2005).

Exchangeable sodium and potassium $\left(\mathrm{Na}^{+}\right.$and $\mathrm{K}^{+}$) were determined using the flame photometry method (Moss, 1961). To determine $\mathrm{K}^{+}$and $\mathrm{Na}^{+}$, standard solution of $0,2,4,68$ and $10 \mathrm{ppm} \mathrm{K}$ and $\mathrm{Na}$ were prepared by diluting appropriate volumes of $100 \mathrm{ppm} \mathrm{K}^{+}$and $\mathrm{Na}^{+}$in volumetric flask using distilled water (Moss, 1961). 
Ammonium acetate $\left(1 \mathrm{~N} \mathrm{NH}_{4} \mathrm{OAc}\right) 77.08 \mathrm{~g}$ of $\mathrm{NH}_{4} \mathrm{OAc}$ was dissolved into $800 \mathrm{ml}$ with water, then neutralised with concentrated $\mathrm{NH}_{4}-\mathrm{H}$ to $\mathrm{pH}$ 7.0. The solution was then diluted to 1 liter. A $10 \mathrm{~g}$ of soil was weighed into extractable bottle and $100 \mathrm{ml}$ of $1 \mathrm{~N} \mathrm{NH}_{4} \mathrm{OAc}$ solution added. This was placed in a bottle with content and then put in a shaking machine for one hour. The bottle with its content was centrifuged for about 20 minutes and the supernatant solution was filtered. The extract was then sprayed into the flame and the photometer read. The milliequivalents of the exchangeables $\mathrm{K}$ was then calculated by reading the flame photometer. Standard curve was constructed where potassium and sodium concentrations in the soil extract were read. To determine exchangeable $\mathrm{Ca}^{2+}$ and $\mathrm{Mg}^{2+}, 10 \mathrm{ml}$ of the extract used to determine potassium and sodium was transferred to an Erlenmeyer flask and $5 \mathrm{ml}$ of an ammonium chloride-ammonium hydroxide buffer solution added followed by addition of $1 \mathrm{ml}$ triethanolamine. A few drops of potassium cyanide and Eriochrome Black T solutions were then added. The mixture was then titrated with $0.02 \mathrm{M}$ EDTA solution from a red to a blue end point.

The $\mathrm{pH}$ was determined using the 1:1 in water method where 1:1 proportions of soil and deionized water suspension was stirred vigorously for 20 minutes and left to stand for 30 minutes before measurement with $\mathrm{pH}$ electrode (Page et al., 1982; Black, 1965). Electrical conductivity was measured by treating $10.0 \mathrm{~g}$ of soil with $10 \mathrm{ml}$ of deionized water and the suspension stirred for 1 hour and allowed to settle for 30 minutes. The conductivity meter was calibrated using $\mathrm{KCl}$ reference solution at the temperature of the suspension after which electrodes were dipped in the supernatant and the readings taken (Black, 1965).

Soil organic carbon (SOC) was determined by a modified Walkley-Black procedure as described by Nelson and Sommers (1982). The organic carbon was oxidized by a known concentration of potassium dichromate $(0.166 M)$ solution added in excess. The excess unreacted dichromate was titrated with $0.5 \mathrm{M}$ ammonium iron (II) sulphate in a redox reaction using a diphenylamine indicator. The soil organic matter (SOM) was calculated by multiplying the percentage $\mathrm{C}$ by the factor 1.724 to convert to organic matter (Black, 1965; Wakley and Black, 1934). Soil total nitrogen was determined using the micro Kjeldahl distillation and titration method (Bremner and Mulvaney, 1982). A $1 \mathrm{~g}$ soil sample was weighed into a digestion flask, $5 \mathrm{ml}$ concentrated sulphuric acid and few drops of $30 \%$ hydrogen peroxide were added with selenium to serve as catalyst after which the content was digested. The use of this method converts organic nitrogen to ammonium sulphate and the resultant solution made alkaline by the addition of $5 \mathrm{ml}$ of $40 \%$ sodium hydroxide and ammonia distilled into $2 \%$ boric acid and titrated with standard hydrochloric acid.

\subsection{Statistical Analysis}

Soil physical and chemical properties were compared using a t-test analysis using Instat + version 3.36 package (Dytham, 2011) for both CPS and CS samples. The relationship between soils parameters for CPS and CS soils was tested using correlation of Pearson.

\section{Results and Discussions}

\subsection{Effect of Charcoal Production on Physical and Chemical Properties of Soil}

Table 1 presents results of physical and chemical properties of soil in charcoal production site (CPS) and control site (CS). The analysis of soil particle size showed a signficant difference $(p<0.01)$ between the charcoal production site and the control. There was significantly $(p<0.01)$ higher content of clay at the CPS compared to CS. This difference was significantly higher at the top soil $0-30 \mathrm{~cm}(p<0.01)$ than the subsoil $30-60 \mathrm{~cm}(p<0.05)$. There was significantly $(p<0.01)$ higher content of sand at the topsoil $0-30 \mathrm{~cm}$ of the CPS than the CS while no significant difference $(p>0.05)$ was observed at the subsoil $30-60 \mathrm{~cm}$. The fraction of sand in CPS was higher by $45 \%$ compared to CS within $0-30 \mathrm{~cm}$ soil depth as a result of charcoal production. There was no significant difference $(p>0.05)$ observed in silt between the two sites for both depths $(0-30 \mathrm{~cm}$ and $30-60 \mathrm{~cm}$ ).

This results is in line with the findings of Ogundele et al. (2011), who assessed impacts of charcoal production on soil properties in the derived savanna at Oyo State in Nigeria, and concluded that there were significant differences between soil physical properties in burnt (CPS) and unburnt sites (CS) within the 0-10 cm sampled. Abebe and Endalkachew (2011) also had similar finding in a study in south-western Ethiopia. Contuary to the report by Ogundele et al. (2011) who found significant difference in silt, in this study there was no significant difference in silt content at both depth between CPS and CS. Reasons for the difference in the findings may be due to geographical location, period of sampling and probabily composition of the soil itself. The findings however, is in line with the findings of Oguntunde et al. (2008) who assessed the impacts of charcoal production on soil properties in Ejura in the forest transition zone of Ghana. The geographical location, the underlying parent materials may account for the similarity in the case of Ejura findings and this resaerch, since the soils of both research areas are partly influenced by the Voltaian formation. The high content of sand in CPS compared 
to CS can be attributed to the heating of the soil. When clay particles are exposed to high temperatures, it aggregates to form sand-sized particles, which results in a loosely structured soil. Clay soils become coarse due to severe heating of the surface, resulting in poor water-holding capacity (Ulery \& Graham, 1993) hence, affecting soil moisture availability for the growth and development of crops. The occurrence of drought condition at some critical stage such as flowering or grain filling of crops will result in lower yield. The drying up of soil as a result of high temperature from the heat produced also affects the activities of microorganisms; leading to reduced ecosystem services, and biodiversity.

Similarly, potassiun significantly $(p<0.05)$ increase at the topsoil $(0-30 \mathrm{~cm})$, with $44.2 \%$ more potassium content in CPS comapred to CS. There was however no significant $(p>0.05)$ differences observed at $30-60 \mathrm{~cm}$ depth between CPS and CS although potassim at CPS was slightly higher than CS. The high exchangeable potassium in CPS can be attributed to ash deposit in the soil, as the trees used for the charcoal production may have high level of this mineral in them. This finding is in line with the findings of Abebe and Endalkachew (2011) and Oriola and Omofoyewa (2013) who reported an increase in potassium content by $460.4 \%$ at the kiln site compared to the control. This was however contrary to the findings of Oguntunde et al. (2008) who reported low potassium content in soil at klin site compared to the control and attributed that to low level of potassium in trees used for charcoal production.

Significant differennces were observed in the content of sodium at both depths between the CPS and CS. Sodium was significantly $(p<0.01)$ higher by $15.4 \%$ at $0-30$ and $15.8 \%$ higher $(p<0.05)$ at $30-60 \mathrm{~cm}$ in CS compared to CPS. Calcium content at CS was slightly higher than at CPS, with CS higher by $2.4 \%$ within $0-30$ $\mathrm{cm}$ depth. There was no significant difference in calcium content between CPS and CS within $30-60 \mathrm{~cm}$ depth. In addition, Magnesium was significantly higher by $45.7 \%$ in CS compared to CPS within $0-30 \mathrm{~cm}$. There was no significant difference at the $30-60 \mathrm{~cm}$ depth. This finding is contrary to the finding of Abebe and Endalkachew (2011) who reported an increase in $\mathrm{Na}^{+}$and $\mathrm{Ca}^{2+}$ content in CPS by 178.6 and $64.5 \%$ when compared to CS. Similarly, Blanca et al. (2008) reported an increase in concentrations of exchangeable $\mathrm{K}^{+}, \mathrm{Ca}^{2+}$, and $\mathrm{Mg}^{2+}$ by 1.6 times at kiln sites compared to the adjacent site. They attributed this to the accumulation of wood ashes (2008). Brady and Weil (2008) reported that the addition of ash or deposite due to charcoal production increases content of calcium and some other soil properties and could be the reason for the significant higher calcium content in theburnt site than the unburnt sites. This difference could be due to the type of trees used for charcoal production and also the level of exposure of the soil to heat.

The average percent carbon in soils at the control site (CS) was significantly higher $(p<0.01)$ at both depths by $46.7 \%(0-30)$ and $44.4 \%(30-60 \mathrm{~cm})$ when compared to the charcoal production site (CPS). The soil organic matter was also significantly higher $(p>0.05)$ by $44 \%$ at the CS compared to CPS at the topsoil $0-30 \mathrm{~cm}$. Similarly, there was a significant $(p<0.01)$ difference at $30-60 \mathrm{~cm}$ depth with $50 \%$ higher orgamic matter in the CS compared to CPS. This difference is attributed to accumulation of plant litter on the CS compared to the CPS where the litter or organic matter got burnt by the heat from the charcoal burning.

Similarly, total nitrogen was significantly $(p<0.01)$ higher at CS when compared with CPS for Both depths. Total nitrogen at CS was higher by 75 and $80 \%$ in $0-30$ and $30-60 \mathrm{~cm}$ respectively, when compared with CPS. Consistent burning in the study area may probably account for the lower nitrogen content recorded in soils at CPS.

There was, however, no significant difference $(p>0.05)$ in soil $\mathrm{pH}$ under both CPS and CS, however $\mathrm{pH}$ in CPS were sightly alkaline than CS. The results show that the impact of charcoal burning on soil chemical properties may be limited to the top $0-30 \mathrm{~cm}$. This finding is similar to the finding of Oguntunde et al (2008).

Furthermore, saturated-hydraulic conductivity was significantly higher at both 0-30 $\mathrm{cm}(p<0.01)$ and 30-60 $\mathrm{cm}(p<0.05)$ in CPS than CS. Saturated hydraulic conductivity in CPS significantly $(p<0.01)$ increased by $72.2 \%$ and 4.7 at $0-30 \mathrm{~cm}$ and $30-60 \mathrm{~cm}$ depth respectively when compared with CS. This may be attributed to the increased in sand particle content in the soil at the CPS. Ajayi et al., (2009) reported that a higher infiltration rates at kiln site resulted in a $37 \%$ reduction of runoff.

Aslo, electrical conductivity was significantly higher $(p<0.05)$ in CPS compared to CS at the top $0-30 \mathrm{~cm}$, however, no significant difference within the $30-60 \mathrm{~cm}$ was observed. Electrical conductivity increased by $43.7 \%$ within $0-30 \mathrm{~cm}$ but reduced by $17.4 \%$ at $30-60 \mathrm{~cm}$ when compared with CS. These can be attributed to the ashes produced from the charcoal which contain high content of basic cations. Similar findings was reported by Abebe and Endalkachew (2011) who stated a 6 time fold increase in Electrical conductivity at the kiln site than the adjacent side (control). 
Table 1. Summary of statistics of soil properties within the depths $0-30$ and $30-60 \mathrm{~cm}$ at both CPS and CS sites

\begin{tabular}{|c|c|c|c|c|c|c|c|c|c|c|}
\hline \multirow[b]{2}{*}{ Property } & \multirow[b]{2}{*}{ Depth (cm) } & \multicolumn{3}{|c|}{ Burnt site (CPS) } & \multicolumn{3}{|c|}{ Control site (CS) } & \multirow[b]{2}{*}{$t$-value } & \multirow[b]{2}{*}{ p-value } & \multirow[b]{2}{*}{$F$ - probabilit } \\
\hline & & Mean \pm S.D & Minimum & Maximum & Mean \pm S.D & Minimum & Maximum & & & \\
\hline \multirow[t]{2}{*}{ Clay } & $0-30$ & $14.7 \pm 4.8$ & 6.0 & 22 & $24.9 \pm 6.1$ & 15 & 35 & 5.56 & 0.001 & $* *$ \\
\hline & $30-60$ & $17.7 \pm 6.0$ & 7.0 & 32 & $23.5 \pm 6.4$ & 15 & 33 & 2.63 & 0.014 & $*$ \\
\hline \multirow[t]{2}{*}{ Sand } & $0-30$ & $75.2 \pm 8.1$ & 62 & 88 & $60.7 \pm 11.8$ & 44 & 80 & 3.92 & 0.001 & $* *$ \\
\hline & $30-60$ & $69.7 \pm 7.8$ & 54 & 80 & $61.0 \pm 10.7$ & 33 & 75 & 2.54 & 0.055 & NS \\
\hline \multirow[t]{2}{*}{ Silt } & $0-30$ & $10.7 \pm 4.7$ & 2.0 & 16 & $13.8 \pm 7.3$ & 3.0 & 30 & 1.84 & 0.761 & NS \\
\hline & $30-60$ & $12.6 \pm 5.0$ & 3.0 & 19 & $14.6 \pm 6.2$ & 9.0 & 34 & 1.47 & 0.154 & NS \\
\hline \multirow[t]{2}{*}{$\mathrm{K}^{+}$} & $0-30$ & $0.52 \pm 0.21$ & 0.15 & 0.94 & $0.29 \pm 0.14$ & 0.12 & 0.59 & 3.35 & 0.002 & $* *$ \\
\hline & $30-60$ & $0.36 \pm 0.21$ & 0.08 & 0.80 & $0.29 \pm 0.11$ & 0.10 & 049 & 1.12 & 0.274 & NS \\
\hline \multirow[t]{2}{*}{$\mathrm{Ca}^{2+}$} & $0-30$ & $8.57 \pm 2.85$ & 4.13 & 13.10 & $8.78 \pm 6.22$ & 1.59 & 23.81 & 0.12 & 0.905 & NS \\
\hline & $30-60$ & $6.72 \pm 2.88$ & 3.14 & 12.26 & $9.13 \pm 8.29$ & 2.33 & 33.64 & 1.06 & 0.302 & NS \\
\hline \multirow[t]{2}{*}{$\mathrm{Na}^{+}$} & $0-30$ & $0.66 \pm 0.12$ & 0.49 & 0.91 & $0.78 \pm 0.16$ & 0.47 & 1.1 & 2.32 & 0.028 & * \\
\hline & $30-60$ & $0.54 \pm 0.10$ & 0.39 & 0.71 & $0.76 \pm 0.13$ & 0.57 & 0.94 & 5.01 & 0.001 & $* *$ \\
\hline \multirow[t]{2}{*}{$\mathrm{Mg}^{2+}$} & $0-30$ & $1.78 \pm 0.36$ & 1.37 & 2.70 & $3.28 \pm 1.96$ & 1.49 & 7.94 & 2.92 & 0.011 & $*$ \\
\hline & $30-60$ & $1.71 \pm 0.66$ & 1.01 & 3.86 & $5.26 \pm 7.14$ & 1.39 & 27.55 & 1.92 & 0.076 & NS \\
\hline \multirow[t]{2}{*}{$\mathrm{C}$} & $0-30$ & $0.8 \pm 0.3$ & 0.3 & 1.4 & $1.5 \pm 0.8$ & 0.4 & 3.4 & 2.93 & 0.007 & $* *$ \\
\hline & $30-60$ & $0.4 \pm 0.2$ & 0.01 & 0.74 & $0.9 \pm 0.7$ & 0.2 & 2.7 & 2.93 & 0.007 & $* *$ \\
\hline \multirow[t]{2}{*}{$\mathrm{OM}$} & $0-30$ & $1.4 \pm 0.6$ & 0.6 & 2.5 & $2.5 \pm 1.5$ & 0.03 & 5.9 & 2.48 & 0.021 & $*$ \\
\hline & $30-60$ & $0.6 \pm 0.4$ & 0.01 & 1.28 & $1.6 \pm 1.2$ & 0.3 & 4.7 & 3 & 0.006 & $* *$ \\
\hline \multirow[t]{2}{*}{$\mathrm{pH}$} & $0-30$ & $6.4 \pm 0.3$ & 6.1 & 7.0 & $6.3 \pm 0.8$ & 4.8 & 7.5 & 0.46 & 0.659 & NS \\
\hline & $30-60$ & $6.4 \pm 0.2$ & 6.1 & 6.7 & $6.3 \pm 0.8$ & 4.5 & 7.2 & 0.1 & 0.923 & NS \\
\hline \multirow[t]{2}{*}{$\mathrm{EC}$} & $0-30$ & $305.3 \pm 149.8$ & 94 & 650 & $172.0 \pm 121.7$ & 50 & 380 & 2.67 & 0.012 & $*$ \\
\hline & $30-60$ & $178.0 \pm 113.2$ & 80 & 400 & $209.3 \pm 157.2$ & 45 & 490 & 0.63 & 0.536 & NS \\
\hline \multirow[t]{2}{*}{$\mathrm{TN}$} & $0-30$ & $0.1 \pm 0.1$ & 0.01 & 0.26 & $0.5 \pm 0.1$ & 0.3 & 0.8 & 10.21 & 0.001 & $* *$ \\
\hline & $30-60$ & $0.08 \pm 0.03$ & 0.04 & 0.15 & $0.5 \pm 0.1$ & 0.4 & 0.6 & 16.2 & 0.001 & $* *$ \\
\hline \multirow[t]{2}{*}{$\mathrm{HC}$} & $0-30$ & $1.8 \pm 1.0$ & 0.6 & 3.9 & $0.5 \pm 0.3$ & 0.1 & 1.1 & 4.67 & 0.001 & $* *$ \\
\hline & $30-60$ & $1.2 \pm 0.8$ & 0.2 & 3.1 & $0.7 \pm 0.4$ & 0.2 & 1.4 & 2.29 & 0.029 & $*$ \\
\hline
\end{tabular}

S.D $=$ Standard deviation, NS = Not significant, $* * *=$ Significant at 0.05 and 0.01 , respectively.

Soil properties such as magnesium, sodium, calcium and potassium were measured in $\left(\mathrm{Cmol}(+) \mathrm{kg}^{-1}\right)$, $\mathrm{sand}$, clay, silt, total nitrogen and organic carbon measured in $(\%)$, electrical conductivity $(\mu \mathrm{S} / \mathrm{cm} 3)$ and hydraulic conductivity $\left(\mathrm{cm} \mathrm{h}^{-1}\right)$.

\subsection{Relationship between Soil Parameters in the CPS and CS}

Relationships between soil parameters were analysed using the correlation of Pearson (Table 2 and 3). A positive significant correlation were observed between $\mathrm{K}^{+}$and Sand, $\mathrm{Na}^{+}$and $\mathrm{K}^{+}, \mathrm{Mg}^{2+}$ and $\mathrm{K}^{+}, \mathrm{Mg}^{2+}$ and $\mathrm{Na}^{+}, \mathrm{C}^{2}$ and $\mathrm{K}^{+}$, $\mathrm{C}$ and $\left(\mathrm{Na}^{+}, \mathrm{Mg}^{2+}\right), \mathrm{OM}$ and $\left(\mathrm{K}^{+}, \mathrm{Na}^{+}, \mathrm{Mg}^{2+}, \mathrm{C}, \mathrm{EC}\right.$ and $\left.\mathrm{Sand}\right), \mathrm{C}$ and $\left(\mathrm{K}^{+}, \mathrm{EC}\right.$ and $\left.\mathrm{Na}^{+}\right) \mathrm{EC}$ and $(\mathrm{C}$, and $\mathrm{OM}), \mathrm{TN}$ and $\mathrm{K}^{+}, \mathrm{HC}$ and Sand, $\mathrm{HC}$ and $\mathrm{K}^{+}, \mathrm{HC}$ and $\mathrm{C}, \mathrm{HC}$ and $\mathrm{OM}$. On the other hand, negative significant correlation was also found between a number of the nutrients as shown in Table 2.

Similarly, positive correlations between soil nutrients in CS were observed as shown in Table 3. The results showed positive significant correlations between Silt and Clay, $\mathrm{Na}$ and $(\mathrm{K}, \mathrm{OM}$ and $\mathrm{C}), \mathrm{pH}$ and $\left(\mathrm{Silt}, \mathrm{K}^{+}, \mathrm{Na}^{+}\right)$. Positive significant correlation was also observed between $\mathrm{EC}$ and (Clay, EC and silt, $\left.\mathrm{Na}^{+}, \mathrm{pH}\right)$ and also $\mathrm{HC}$ and Sand. However, negative significant correlation was observed between Clay and sand, silt and sand, $\mathrm{Na}^{+}$and Sand, PH and Sand, EC and Sand, TN and C, TN and OM, HC and (Clay, Silt and EC). There was, however, no significant correlation observed in the rest of the nutrients. This finding is in line with physic-chemical properties and available nutrients in sandy loam soils report by Chaudhari et al. (2012). 
Table 2. Values of Pearson correlation between top soil $(0-30 \mathrm{~cm})$ parameters at charcoal production site (CPS); $\mathrm{K}^{+}=$potassium, $\mathrm{C}=$ carbon, $\mathrm{Na}^{+}=$sodium, $\mathrm{Ca}^{2+}=$ calcium, $\mathrm{OM}=$ Organic matter, $\mathrm{Mg}^{2+}=$ magnesium, $\mathrm{EC}=$ Electrical conductivity, $\mathrm{TN}=$ Total nitrogen and $\mathrm{HC}=$ Hydraulic conductivity

\begin{tabular}{lccccccccccccc}
\hline Variables & SAND & CLAY & SILT & $\mathrm{K}^{+}$ & $\mathrm{Na}^{+}$ & $\mathrm{Ca}^{2+}$ & $\mathrm{Mg}^{2+}$ & $\mathrm{C}$ & $\mathrm{OM}$ & $\mathrm{pH}$ & $\mathrm{EC}$ & $\mathrm{TN}$ & $\mathrm{HC}$ \\
\hline SAND & 1 & & & & & & & & & & & & \\
CLAY & $-0.806^{* *}$ & 1 & & & & & & & & & & \\
$\mathrm{SILT}$ & $-0.759^{* *}$ & 0.236 & 1 & & & & & & & & & \\
$\mathrm{~K}^{+}$ & $0.481^{*}$ & $-0.501^{* *}$ & -0.243 & 1 & & & & & & & & \\
$\mathrm{Na}^{+}$ & 0.245 & -0.263 & -0.133 & $0.692^{* *}$ & 1 & & & & & & & \\
$\mathrm{Ca}^{2+}$ & 0.266 & -0.007 & $-0.432^{*}$ & -0.014 & 0.111 & 1 & & & & & & \\
$\mathrm{Mg}^{2+}$ & 0.143 & -0.066 & -0.293 & 0.313 & 0.206 & -0.262 & 1 & & & & & \\
$\mathrm{C}$ & 0.328 & $-0.431^{*}$ & -0.097 & $0.702^{* *}$ & $0.641^{* *}$ & -0.055 & 0.276 & 1 & & & & \\
$\mathrm{OM}$ & 0.301 & $-0.411^{*}$ & -0.076 & $0.700^{* *}$ & $0.660^{* *}$ & -0.077 & 0.293 & $0.994^{* *}$ & 1 & & & \\
$\mathrm{pH}$ & 0.028 & -0.067 & -0.006 & 0.191 & 0.133 & 0.212 & 0.108 & 0.206 & 0.167 & 1 & & \\
$\mathrm{EC}$ & $0.411^{*}$ & $-0.448^{*}$ & -0.222 & $0.571 * *$ & $0.725^{* *}$ & $-0.372 *$ & 0.235 & $0.645^{* *}$ & $0.648^{* *}$ & 0.193 & 1 & & \\
$\mathrm{TN}$ & 0.095 & -0.125 & -0.022 & $0.454^{* *}$ & 0.305 & -0.045 & 0.018 & 0.338 & 0.335 & 0.078 & 0.244 & 1 & \\
$\mathrm{HC}$ & $0.750^{* *}$ & $-0.888^{* *}$ & -0.256 & $0.384^{*}$ & 0.140 & 0.086 & 0.054 & $0.414^{*}$ & $0.394 *$ & -0.029 & 0.355 & 0.083 & 1 \\
\hline
\end{tabular}

** Correlation is significant at the 0.01 level (2-tailed); * Correlation is significant at the 0.05 level (2-tailed).

Soil properties such as magnesium, sodium, calcium and potassium measured in $\left(\mathrm{Cmol}(+) \mathrm{kg}^{-1}\right)$, sand, clay, silt, total nitrogen and organic carbon measured in (\%), electrical conductivity $(\mu \mathrm{S} / \mathrm{cm} 3)$ and hydraulic conductivity $\left(\mathrm{cm} \mathrm{h}^{-1}\right)$.

Table 3. Values of Pearson correlation between top soil $(0-30 \mathrm{~cm})$ parameters at control site $(\mathrm{CS}) ; \mathrm{K}^{+}=$ potassium, $\mathrm{C}=$ carbon, $\mathrm{Na}^{+}=$sodium, $\mathrm{Ca}^{2+}=$ calcium, $\mathrm{OM}=$ Organic matter, $\mathrm{Mg}^{2+}=$ magnesium, $\mathrm{EC}=$ Electrical conductivity $\mathrm{TN}=$ Total nitrogen and $\mathrm{HC}=$ Hydraulic conductivity

\begin{tabular}{|c|c|c|c|c|c|c|c|c|c|c|c|c|c|}
\hline Variables & SAND & CLAY & SILT & $\mathrm{K}^{+}$ & $\mathrm{Na}^{+}$ & $\mathrm{Ca}^{2+}$ & $\mathrm{Mg}^{2+}$ & $\mathrm{C}$ & $\mathrm{OM}$ & $\mathrm{pH}$ & $\mathrm{EC}$ & $\mathrm{TN}$ & $\overline{\mathrm{HC}}$ \\
\hline SAND & 1 & & & & & & & & & & & & \\
\hline CLAY & $-0.850 * *$ & 1 & & & & & & & & & & & \\
\hline SILT & $-0.875^{* *}$ & $0.494 * *$ & 1 & & & & & & & & & & \\
\hline $\mathrm{K}^{+}$ & -0.075 & 0.024 & 0.111 & 1 & & & & & & & & & \\
\hline $\mathrm{Na}^{+}$ & $-0.388^{*}$ & 0.334 & 0.351 & $0.559 * *$ & 1 & & & & & & & & \\
\hline $\mathrm{Ca}^{2+}$ & $-0.381 *$ & $0.435^{*}$ & 0.256 & 0.253 & $0.406^{*}$ & 1 & & & & & & & \\
\hline $\mathrm{Mg}^{2+}$ & -0.246 & 0.138 & 0.269 & -0.006 & 0.177 & 0.001 & 1 & & & & & & \\
\hline $\mathrm{C}$ & 0.147 & -0.194 & -0.068 & 0.221 & 0.043 & -0.183 & 0.184 & 1 & & & & & \\
\hline $\mathrm{OM}$ & 0.178 & -0.240 & -0.076 & 0.225 & 0.010 & -0.208 & 0.178 & $0.995^{* *}$ & 1 & & & & \\
\hline $\mathrm{pH}$ & $-0.488 * *$ & 0.353 & $0.491 * *$ & $0.432 *$ & $0.511 * *$ & $0.410^{*}$ & 0.128 & 0.082 & 0.059 & 1 & & & \\
\hline $\mathrm{EC}$ & $-0.600 * *$ & $0.575^{* *}$ & $0.485^{* *}$ & 0.287 & $0.613 * *$ & $0.634 * *$ & 0.140 & -0.120 & -0.164 & $0.516^{* *}$ & 1 & & \\
\hline $\mathrm{TN}$ & -0.219 & 0.214 & 0.140 & -0.144 & 0.021 & 0.201 & -0.051 & $-0.369^{*}$ & $-0.378^{*}$ & 0.048 & 0.347 & 1 & \\
\hline $\mathrm{HC}$ & $0.825 * *$ & $-0.951 * *$ & $-0.491 * *$ & -0.113 & -0.287 & -0.359 & -0.105 & 0.112 & 0.143 & -0.319 & $-0.493 * *$ & -0.164 & 1 \\
\hline
\end{tabular}

** Correlation is significant at the 0.01 level (2-tailed). * Correlation is significant at the 0.05 level (2-tailed).

Soil properties such as magnesium, sodium, calcium and potassium measured in $\left(\mathrm{Cmol}(+) \mathrm{kg}^{-1}\right)$, sand, clay, silt, total nitrogen and organic carbon measured in (\%), electrical conductivity $(\mu \mathrm{S} / \mathrm{cm} 3)$ and hydraulic conductivity $\left(\mathrm{cm} \mathrm{h}^{-1}\right)$.

\section{Conclusion}

This study investigated the impact of charcoal production on soils physical and chemical properties in Northern Ghana. Most of the physical and chemical properties selected have been significantly impacted by charcoal production. The earth kiln method used by the charcoal producers in this district significantly increased the 
percentage of sand content and decreased clay and silt content in the soil. In addition, percent carbon, exchangeable, $\mathrm{Mg}, \mathrm{Na}, \mathrm{K}, \mathrm{Ca}$, and electrical conductivity were significantly higher in soil at charcoal production site than in the corresponding control site.

Measured hydraulic conductivity increased on the CPS soils, which is likely to result in increased drainage and hence decrease soil erosion. The coarsening of soil particles has implication for water-holding capacity resulting in less moisture availability for crops use and likely leaching of plant nutrients.

\section{Recommendations}

The earth kiln method of charcoal production pollutions the air and contribute to climate change. More improved method of charcoal production should be used which will have less impact on the soil and the environment as a whole. The study revealed indiscriminate felling of trees for charcoal prodction (data not included) which is gradually changeing the ecology of the area. The assembly should collaborate with the traditional rulers to develop workable by-laws to regulate the charcoal trade. Woodlot should be established in the area where the producers of charcoal can use them for charcoal production. There is a need for further research on the impact of charcoal production on soil nutrient, hydrology and crop production.

\section{References}

Abebe, N., \& Endalkachew, K. (2011). Effect of Charcoal Production on Soil Properties in Southwestern Ethiopia. Middle-East Journal of Scientific Research, 9(6), 807-813.

Ajayi A., Oguntunde P., Abiodun J., \& Moacir de Souza, D. J. (2009). Numerical analysis of the impact of charcoal production on soil hydrological behavior, runoff response and erosion susceptibility. Rev Bras Ciênc Solo, 33, 137- 45. http://dx.doi.org/10.1590/S0100-06832009000100015

Arnalds, Ó., Thorarinsdottir, E. F., Metusalemsson, S., Jónsson, Á., \& Arnason, A. (2001). Soil erosion in Iceland. Agricultural Research Institute, Soil Conservation Service.

Bainbridge, D. A. (2007). A guide for desert and dryland restoration: new hope for arid lands. Island Press.

Blanca, E. G. M., Mosqueda, C. R., Dendooven, L., Vázquez-Marrufo, G., \& Olalde-Portugal, V. (2008). Charcoal Production at Kiln Sites Affects $\mathrm{C}$ and N Dynamics and Associated Soil Microorganisms in Quercus spp. Temperate Forests of Central Mexico.

Bojo, J. (1996). The costs of land degradation in Sub-Saharan Africa. Ecological economics, 16, 161-173. The World Bank, 1818 H Street, Washington, DC 20433, USA.

Brady, N. C., \& Weil, R. R. (2008). The nature and properties of soils (pp. 962-994). Singapore. Prentice Hall, Upper Saddle River, N.J. .

Bremner, J. M., \& Mulvaney, V. A. (1982). Steam distillation methods for ammonium nitrate and nitrite. Anal Chim Acta, 32, 485-495. http://dx.doi.org/10.1016/S0003-2670(00)88973-4

Chaudhari, P. R., Ahire, D. V., \& Ahire, V. D. (2012). Correlation between physic-chemical perties and available nutrients in sandy loam soils of Haridwar. Journal of chemical, Biological and Physical Sciences, 2(3).

Chidumayo, N. E. (2011). Environmental Impacts of Charcoal Production in Tropical Ecosystems of the World. Paper presented at the 2011 Annual Conference of the Association for Tropical Biology and Conservation, and society for Conservation Biology, June, 12-16, Arusha, Tanzania.

Dietrich, H. (2005). Standard operating procedure: Procedure for determining soil particle size using the hydrometer method. California Department of Pesticide Regulation, Environmental Monitoring Branch (pp. 1-10).

Dytham, C. (2011). Choosing and using statistics: a biologist's guide. John Wiley \& Sons.

Eswaran, H. R., Lal, R., \& Reich, P. F. (2001). Land degradation: An overview. In E. M. Bridges (Eds.), Responses to land degradation. Proceedings of $2^{\text {nd }}$ international conference on land degradation and desertification, Khon Kaen, Thailand. Oxford press, New Delhi, India.

FAO. (1987). Simple technologies for charcoal making. Rome, Italy: Food and Agriculture Organization of the United Nations, FAO Forestry Paper 41. Retrieved from http://www.fao.org/docrep/x5328e/x5328e00.htm \#Contents.

FAO. (2000). The challenge of rural energy and poverty in developing countries. World Energy Council/Food and Agriculture Organization of the United Nations, London.

Fosu, M., Kuhne, R. F., \& Vlek, P. L. G. (2004) Improving maize yield in the Guinea savannah zone of Ghana with leguminous cover crops and P K fertilization. J Agron, 3(2), 115-121. http://dx.doi.org/10.3923/ja.2004.115.121 
Fosu-Mensah, B. Y. (2012). Modelling maize (Zea mays L.) productivity and impact of climate change on yield and nutrient utilization in sub-humid Ghana. $\mathrm{PhD}$ thesis, Zentrum für Entwicklungsforschung, University of Bonn.

Ghana Energy Commission. (2010). Bio-energy Draft Policy for Ghana, Accra, 10, 25.

Ikurekong, E. E., Esin, J. O., \& Mba, A. C. (2009). Rural Fuelwood Exploitation in Mbo Local Government Area - A Nigerian Coastal Settlement. Ethiopian Journal of Environmental Studies and Management, 2(3).

Kammen, M. D., \& Lew, J. D. (2005). Review of Technologies for the Production and Use of Charcoal. Energy and Resources Group and Goldman School of Public Policy. University of California, Berkeley, CA 94720-3050.

Klute, A., \& Dirksen, C. (1986). Hydraulic conductivity and diffusivity. In A. Klute (Ed.), Methods of soil analysis. Physical and mineralogical methods. Madison, American Society of Agronomy,. Part 1. p.687-734.

Malimbwi, R. E., Nduwamungu, J., Misana, S., Jambiya, G. C., Monela, G. C., \& Zahabu, E. (2004). Charcoal supply in Dar es Salaam city, Tanzania. Tanzania journal of forestry and nature conservation, 75.

Msuya, N., Enock, M., \& Abrahamu, K. T. (2011). Environmental Burden of Charcoal Production and Use in Dar es Salaam, Tanzania. Journal of Environmental Protection, 2, 1364-1369. http://dx.doi.org/10.4236/jep. 2011.210158

Nkongolo, N. V., Kuramochi, K., \& Hatano, R. (2008). Effect of mechanized tillage operations on soil physical properties and greenhouse gases fluxes in two agricultural fields. Res. J. Environ. Sci., 2, 68-80.

Nyame, F. K., \& Danso, S. K. A. (2006). Socio-economic, environmental and policy implications of alluvial diamond mining in the Birim diamondiferous field, Eastern Ghana. In G. Hilson (Ed.), Small-scale mining, rural subsistence and poverty in West Africa (pp. 219-226). Intermediate Technology Publications, Rugby

Ogundele, A. T., Eludoyin, O. S., \& Oladapo O. S. (2011). Assessment of impacts of charcoal production on soil properties in the derived savanna, Oyo State, Nigeria. Journal of Soil Science and Environmental Management, 2(5), Retrieved from http://www.academicjournals.JSSEM

Oguntunde, P. G., Abiodun, B. J., Ajayi, A. E., \& van de Giesen, N. (2008). Effects of charcoal production on soil physical properties in Ghana. Z. Pflanzenernähr. Bodenk., 171, 591-596. http://dx.doi.org/10.1002/jpln. 200625185.

Oguntunde, P. G., Matthias, F., Ayodele, E. A., \& Nick, G. (2004). Effects of charcoal production on maize yield: Chemical properties and texture of soil. Bio Fertil soils, 39, 295-299. http://dx.doi.org/10.1007/s 00374-003-0707-1.

Oriola, E., \& Omofoyewa, O. (2013). Impact of Charcoal Production on Nutrients of Soils under Woodland Savanna Part of Oyo State, Nigeria. Journal of Environment and Earth Science, 3(3).

Parker, B. Q., Osei, B. A., Armah, F. A. \& Yawson, D. O. (2010). Impact of biomass burning on soil organic carbon and the release of carbon dioxide into the atmosphere in the coastal savanna ecosystem of Ghana. $J$. Renewable Sustain. Energy, 2. http://dx.doi.org/10.1063/1.3449299

Stefan, H. (2009). Renewable energy in Ethiopia: 13 Months of sunshine for a sustainable development. Germany (pp. 1-20). Retrieved from http://www.stefanheimann.eu/inhalt/Renewables_Ethiopia.pdf

Syaufina, L., \& Ainuddin, A. N. (2011). Impacts of fire on Southeast Asia tropical forests biodiversity: A review. Asian J. Plant Sci., 10, 238-244. http://dx.doi.org/10.3923/ajps.2011.238.244

Ulery, A. L., \& Graham, R. C. (1993). Forest fire effects on soil color and texture. Soil Sci. Soc. Am. J., 57, 135-140. http://dx.doi.org/10.2136/sssaj1993.03615995005700010026x

Walkley, A., \& Black, I. A. (1934). An examination of Degtjareff method for determining soil organic matter and a proposed modification of the chromic acid titration method. Soil Sci., 37, 29-37. http://dx.doi.org/10.1097/00010694-193401000-00003

\section{Copyrights}

Copyright for this article is retained by the author(s), with first publication rights granted to the journal.

This is an open-access article distributed under the terms and conditions of the Creative Commons Attribution license (http://creativecommons.org/licenses/by/3.0/). 